\title{
Titanium Alloy Ti-6Al-4V Prepared by Selective Laser Melting (SLM)
}

Michaela Fousová, Dalibor Vojtěch, Jiří Kubásek

Department of Metals and Corrosion Engineering, Faculty of Chemical Technology, University of Chemistry and Technology Prague, 16628 Prague 6. Czech Republic. E-mail: fousovam@vscht.cz, dalibor.vojtech@vscht.cz, jiri.kubasek@vscht.cz

Selective laser melting (SLM) as a representant of additive manufacturing technology brings about many advantages into production, which are appreciated especially in the field of biomedical applications and implantology. Our paper is focused on characterization of titanium alloy Ti-6Al-4V (Ti Grade 5) widely used for orthopaedic implants produced by this novel method. Microstructure and mechanical properties are compared with the same material prepared by conventional way of casting, forging and machining. Results show these are almost equivalent. Microstructure is in both cases formed by two phases $\alpha+\beta$, but possesses different morphology. Yield strength and ultimate tensile strength of SLM material slightly overpassed values obtained by conventional commercial production (950 MPa and $1000 \mathrm{MPa}$ vs. $877 \mathrm{MPa}$ and $985 \mathrm{MPa}$ ). Only elongation was reduced resulting from the presence of some porosity. However, by future optimalization of SLM process parameters, porosity is expected to decrease.

Keywords: titanium alloy, SLM, 3D printing, mechanical properties

\section{Acknowledgement}

Authors wish to thank the Czech Science Foundation (project no. P108/12/G043) and specific university research (MSMT No 20-SVV/2016) for the financial support of this research. Furthermore, authors thank to Prospon spol. s.r.o. for providing the test material.

\section{References}

[1] BANDYOPADHYAY, A., ESPANA, F., BANNA, V. K., ET AL. (2010). Influence of porosity on mechanical properties and in vivo response of Ti6Al4V implants. In: Acta Biomaterialia, Vol. 6, No. 4, pp. 1640-1648. Elsevier Ltd.

[2] ÖZCAN, M., HÄMMERLE, C. (2012). Titanium as a reconstruction and implant material in dentistry: advantages and pitfalls. In: Materials, Vol. 5, No. 9, pp. 1528-1545. MDPI AG, Basel, Switzerland.

[3] KRISHNA, B. V., BOSE, S., BANDYOPADHYAY, A. (2007). Low stiffness porous Ti structures for load-bearing implants. In: Acta Biomaterialia, Vol. 3, No. 6, pp. 997-1006. Elsevier Ltd.

[4] PETERS, M., HEMPTENMACHER, J., KUMPFERT J., LEYENS, C. (2003). Structure and Properties of Titanium and Titanium Alloys. In: Titanium and Titanium Alloys: Fundamentals and Applications (Leyens C., Peters, M. (Ed.)), pp. 1-35. Wiley-WCH GmbH \& Co. KGaA: Weinheim.

[5] STANCEKOVA, D., SEMCER, J., RUDAWSKA, A., CEP, R. (2015). Identification of drilling of biocompatible materials based on titanium. In: Manufacturing Technology, Vol. 15, No. 4, pp. 699-704. Czech Republic.

[6] ZHANG, L. C., ET AL. (2011). Manufacture by selective laser melting and mechanical behavior of a biomedical Ti-24Nb-4Zr-8Sn alloy. In: Scripta Materialia, Vol. 65, No. 1, pp. 21-24. Elsevier Ltd.

[7] KURODA, D., ET AL. (1998). Design and mechanical properties of new $\beta$ type titanium alloys for implant materials. In: Materials Science and Engineering: A, Vol. 243, No. 1-2, pp. 244-249. Elsevier Science S. A.

[8] WANG, Y., ET AL. (2010). Development of highly porous titanium scaffolds by selective laser melting. In: Materials Letters, Vol. 64, No. 6, pp. 674-676. Elsevier B. V.

[9] RYAN, G., PANDIT, A., APATSIDIS, D. P. (2006). Fabrication methods of porous metals for use in orthopaedic applications. In: Biomaterials, Vol. 27, No. 13, pp. 2651-2670. Elsevier Ltd.

[10] FOUSOVÁ, M., VOJTĚCH, D., KUBÁSEK, J., DVORSKÝ, D., MACHOVÁ, M. (2015). 3D Printing as an Alternative to Casting, Forging and Machining Technologies? In: Manufacturing Technology, Vol. 15, No. 5, pp. 809-814. Czech Republic.

[11] HOLLANDER, D. A., ET AL. (2006). Structural, mechanical and in vitro characterization of individually structured Ti-6Al-4V produced by direct laser forming. In: Biomaterials, Vol. 27, No. 7, pp. 955-963. Elsevier Ltd. 
[12] LI, J. P., ET AL. (2005). Porous Ti6Al4V scaffolds directly fabricated by 3D fibre deposition technique: Effect of nozzle diameter. In: Journal of Materials Science: Materials in Medicine, Vol. 16, No. 12, pp. 1159-1163. Kluwer Academic Publishers.

[13] OSAKADA, K., SHIOMI, M. (2006). Flexible manufacturing of metallic products by selective laser melting of powder. In: International Journal of Machine Tools and Manufacture, Vol. 46, No. 11, pp. 1188-1193. Elsevier Ltd.

[14] CHLEBUS, E., KUZNICKA, B., KURZYNOWSKI, T., DYBAŁA, B. (2011). Microstructure and mechanical behaviour of $\mathrm{Ti}-6 \mathrm{Al}-7 \mathrm{Nb}$ alloy produced by selective laser melting. In: Materials Characterization, Vol. 62, No. 5, pp. 488-495. Elsevier Inc.

[15] VRANCKEN, B., ET AL. (2012). Heat treatment of Ti6Al4V produced by Selective Laser Melting: Microstructure and mechanical properties. In: Journal of Alloys and Compounds, Vol. 541, pp. 177-185. Elsevier B. V.

[16] MERTENS, A., ET AL. (2014). Mechanical properties of alloy Ti-6Al-4V and of stainless steel 316L processed by selective laser melting: influence of out-of-equilibrium microstructures. In: Powder Metallurgy, Vol. 57, No. 3, pp. 184-189. Maney Publishing.

[17] QIU, C., ADKINS, N. J. E., ATTALLAH, M. M. (2013). Microstructure and tensile properties of selectively lasermelted and of HIPed laser-melted Ti-6Al-4V. In: Materials Science and Engineering: A, Vol. 578, pp. 230-239. Elsevier B. V.

[18] MICHALCOVÁ, A., ET AL. (2015). Microstructures of iron aluminides processed by additive layer manufacturing and spark plasma sintering. In: Manufacturing Technology, Vol. 15, No. 4, pp. 610-614. Czech Republic.

[19] MURR, L.E., ET AL. (2009). Microstructure and mechanical behavior of Ti-6Al-4V produced by rapid-layer manufacturing, for biomedical applications. In: Journal of the Mechanical Behavior of Biomedical Materials, Vol. 2, No. 1, pp. 20-32. Elsevier Ltd. 